\title{
Clinical Experience of Bilateral Rotator Cuff Tear
}

\author{
by \\ Mohammad Ehsanur Rabbi, Nobuyuki Ito, Masao Eto \\ Tadashi Tomonaga and Katsuro Iwasaki \\ Department of Orthopaedic Surgery, \\ Nagasaki University School of Medicine
}

\begin{abstract}
Key words : Bilateral rotator cuff tear (両側腱板断裂), McLaughlin method (McLaughlin 法), heavy worker (重労働者), clinical results (治療成績)
\end{abstract}

\section{Introduction:}

Worker whose occupation requires repeated overhead movemonts and in elderly population as a whole suffer from shoulder problems. Rotator cuff tear is a very common practice to an orthopaedic surgeon, however, bilateral cases of rotator cuff tear are relatively rare. We experienced rotator cuff tears of ten shoulders in five patients in our hospital. The purpose of this study is to report the clinical results and also to investigate the operative indication for the cases with bilateral rotator cuff tear.

Subjects and methods:

One hundred thirty nine shoulders of 134 patients were operated on for rotator cuff tear in our hospital since 1980 to 1994 (Fig. 1). Their average age was $53.4 \pm 8.6$ years. There were 117 males and 17 females. Out of them, five patients had bilateral rotator cuff tears. All of them were right dominant male and at the time of first operation their average age was 47.8 years $(31$ yrs. to 59 yrs.). The patients were all hard laboured; four of them worked in fishing trawler and the other was a carpenter. At first operation right side was affected in three and left side in two patients. The interval between the first and second operation ranged from 3 to 5 years (average: 4.3 yrs.). Seven out of 10 shoulders had definite history of trauma. In

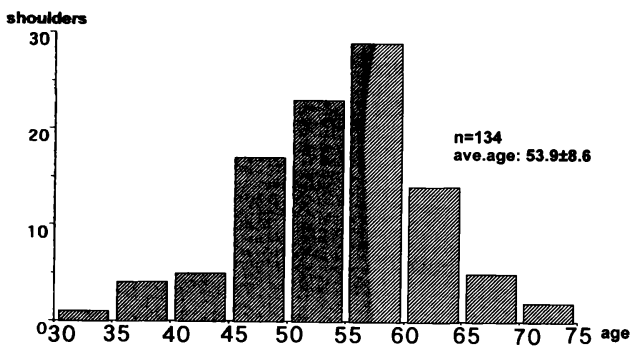

Fig.1 Age distribution of the patients operated for rotator cuff tear in our hospital (1980 $\sim 1994$ ) 
all the shoulders arthroscopy followed by repair of cuff tear was carried out. The operation perform-ed was McLaughlin method (tendon to bone suture) along with lateral acromioplasty and resec-tion of coraco-acromial ligament ${ }^{2) 5}$. The size of the tears was confirmed at operation.

According to Lundberg's classification there were two small, seven medium, and one large tear ${ }^{4}$. The following day of operation all the shoulders were immobilized in a zero position cast. After two weeks they were encouraged to do passive ROM exercise. The follow-up period for the first operation ranged from 7 years 1 month to 13 years 7 months with an average of 9 years 2 months. That of second operation was from 3 years 3 months to 8 years 10 months and the mean period was 4 years 9 months. Pre-and postoperative JOA scores of both operations were investigated and were compared with the scores of another series $(n=100)$ of unilateral rotator cuff tear patients with more that one year of follow up ${ }^{11}$. The period after operation to returning to their job in both operations was also investigated.

\section{Results:}

The average pre-operative JOA score at first operation was $74.6 \pm 7.1$ and the post-operative average JOA score was $94.0 \pm 1.7$. The average pre-operative JOA score of contralateral side was $75.4 \pm 3.0$ and the post-operative average JOA score was $92.2 \pm 1.3$ (Fig. 2). In both times significant improvement of JOA score was noticed post operatively. However, no significant relationship was found between the score of two operations. The pre and post operative JOA scores in 100 shoulders with follow-up periods more than one year were $64.5 \pm 11.2$ and $92.2 \pm 7.3$, respectively. However, those in 10 shoulders were $75.0 \pm 4.9$ and93.6 \pm 2.1 , respectively, showing the pre-operative JOA score was higher in ten shoulders (Fig. 3). The time from the onset of symptoms to first operation ranged from 2 months to 5 months with an average of 3.2 months (excluding one case who had operation after 5 years). Whereas that of second operation range$\mathrm{d}$ from 4 months to 13 months with an average of 8.2 months and was longer at the operation of the contra lateral side. Average time to returning to their previous job after first operation was $5.3 \pm 0.8$ months and that of second operation was $4.2 \pm 1.4$ and was earlier after second op-

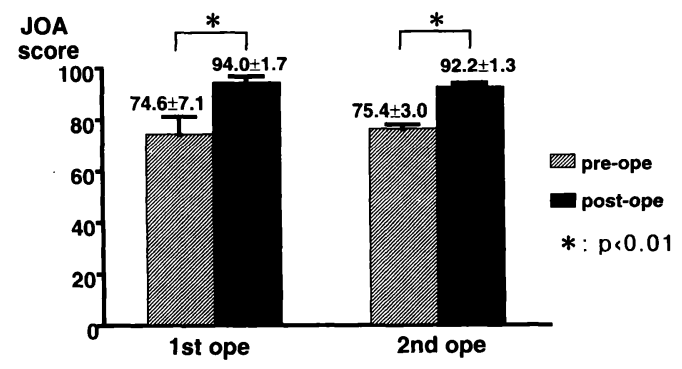

Fig.2 Pre and postoperative JOA scores in both operations

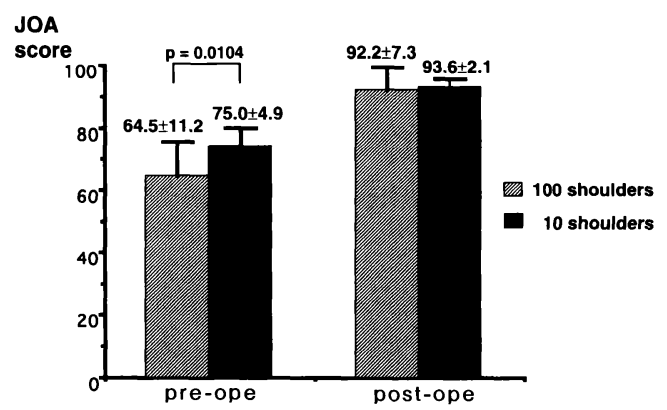

Fig.3 Comparison of pre and postoperative JOA scores between bilateral cuff tear group and another series of cuff tear patients (Graph of another series has been obtained from reference no.1) 
eration $(p=0.0295)$.

\section{Discussion:}

Usually heavy workers has to use their both arms during their work. In rotator cuff tear the elevation of the arm is usually disturbed due to the loss of muscle power: In our this series all the patients were hard labourer and the yused their arms to lift heavy objects as a part of their work. It has been stated that degenerative changes in the shoulder is one of the main cause of rotator cuff rupture ${ }^{3)}$. However, the average age of these 5 patients was slightly less compared to the another group of 100 patients. This may be due to repeated use of their arms in their work, pre-existing changes were present before the tear.

The average pre-operative JOA score was 75 in these patients which was significantly higher compared to the other series. This indicates that heavy workers with rotator cuff tear intends to be operated even with higher JOA score. Because during their work, full strength of the arm is needed and even slight disability makes it difficult for them to perform their work satilsfactorily. Therefore, this may be the reason that heavy working generation desires to be operated with slight deficiency in their work.

Here also considering the dominance of arm, in case of heavy workers this has little importance, because they have to use their both arms simultaneously. Therefore, irrespective of dominant or non-dominant side, operation is indicated for heavy working rotator cuff tear patients.

Except one case, the average time of onset to operation was 3.2 months for the first operation. The first case before visiting our hospital, he consulted many other different hospitals and clinics and this was the reason for the delay in performing operation. Whereas the average time of onset to operation was 8.2 months for the second operation. The time from onset to operation for the second operation was longer than the first time. From the patient's point of view, any person does not want be operated so many times. Therefore, may be they waited and carried on conservative treatment. However, with conservative therapy they were not satisfied and they were having difficulties in their work and finally decided to be operated, because by operation experience of the contra lateral side they were aware of the good outcome.

The average time between first operation and joining to their work was 5.3 months and that was 4.2 months after second operation. This was most probably due to the experience of the first operation. After first operation they underwent physical therapy to improve ROM and muscle power. After second operation they knew exactly what to do post-opratively and they could return to their work earlier.

\section{Conclusion:}

In this series it was observed that these five patients who had blilateral rotator cuff tears, were heavey workers. From this study it can be concluded that for heavy worker as they have to use both arms, without considering the side, patients themselves intend to be operated even if the JOA score is not so poor.

\section{References:}

1) Eto M. et al: The Results of Surgical Treatement for Massive Rotator CuffTears. The Shoulder Joint. Vol.19, 
396-398, 1995. (in Japanese)

2) Ito N. et al: Operative Treatment of Rotator Cuff tear-Mc Laughlin's Method along with Lateral Acromioplasty. Siekeigeka Mook. Vol.2 D : 60-63, 1993. (in Japnese)

3) Ito N. et al: Pathological Changes of the Inferior Surface of the Acromion in Rotator cuff tears. The Journal of West-Japan Society of Orthpasedics \& Traumatology., Vol.43(4) : 387-389, 1994. (in Japanese)

4) Lundberg, J.: The correlation of clinical evaluation with operative findings and prognosis in rotator cuff rupture. Shoulder Surgery, 35-38, Springer-Verlag, Berlin, 1981.

5) Mc Laughlin, H.L.: Lesion of the musculotendinous cuff of the shoulder. Journal of Bone and Joint Surgery. 26: 31-51, 1944.

〈和文抄録〉

\title{
両側雕板断裂例の観血的治療成績
}

\author{
長崎大学整形外科 \\ Mohammad Ehsanur Rabbi - 伊藤 信 之 \\ 衛 藤 正雄・朝 長匡 \\ 岩 崎 勝 郎
}

比較的まれな両側手術を行った腱板完全断裂例の治 療成績を調べ, 手術の適応について検討した。

対象は 5 例 10 屃で, 全例に McLaughlin 法, 烏 口肩峰勒帯切除および肩峰外側部切除を行った. 全例 男性で職業は漁船員, 大工などの重労働者であった。 初回手術時平均年齢は 47.8 歳, 追跡調査期間は平均 9 年 2 カ月であった. 2 回目の時は全例患者が手術を 希望して受診した. 初回手術より平均 5 年後で, 追跡 調査期間は平均 4 年 9 カ月であった.
術前の平均 JOA score は 75.0 で術後は 94.0 に有 意に改善していた，両肩の術前の JOA score および 術後の JOA score に有意差はなかった. 全例初回お よび 2 回目手術後も元の職業に復帰していた。仕事に 復帰するまでの期間は初回手術後が 5.3 力月, 2 回目 が 4.2 カ月であった. 重労働者では利き腕, 非利き腕 にかかわらず, JOA scoreが75点程度で手術を希望 する事がわかった。 